\title{
Incidence of childhood diabetes mellitus in Yorkshire, northern England, is associated with nitrate in drinking water: an ecological analysis
}

\author{
R.C. Parslow ${ }^{1}$, P.A . M cK inney ${ }^{1}$, G. R . L aw ${ }^{1}$, A . Staines ${ }^{2}$, R . Williams ${ }^{2}$, H .J . B odansky ${ }^{3}$ \\ ${ }^{1}$ Paediatric Epidemiology Group, Centre for Health Services Research, University of Leeds, Leeds, UK \\ ${ }^{2}$ Division of Public Health, Nuffield Institute for Health, Leeds, UK \\ ${ }^{3}$ The Diabetes Centre, Leeds General Infirmary, Leeds, UK
}

Summary The relationship between the incidence of childhood-onset insulin-dependent diabetes mellitus and levels of nitrate in drinking water in the former Yorkshire Regional Health Authority was investigated by means of an ecological analysis. A population-based register contributed 1797 0-16-year-olds diagnosed with diabetes between 1978 and 1994. Nitrate data were based on 9330 samples of drinking water tested between 1990 and 1995 in 148 water supply zones, for which 1991 census small area statistics were taken on population density, ethnicity and socio-economic status. Diabetes incidence was positively associated with raised mean nitrate levels with a standardised incidence ratio of 115 in zones with greater than $14.85 \mathrm{mg} \cdot \mathrm{l}^{-1} \quad\left(\chi^{2}=26.81,1 \mathrm{df}\right.$, $p<0.001)$. Significant negative trends were found between standardised incidence ratios and proportion of non-whites in the population $\left(\chi^{2}=33.57,1 \mathrm{df}\right.$, $p<0.001)$, childhood population density $\left(\chi^{2}=30.81\right.$, $1 \mathrm{df}, \mathrm{p}<0.001)$ and the Townsend deprivation score $\left(\chi^{2}=33.89,1 \mathrm{df}, p<0.001\right)$. Poisson regression modelling, adjusting for the other factors, showed a significant increase in relative incidence rate ratio from a baseline of 1 at nitrate levels below $3.22 \mathrm{mg} \cdot \mathrm{l}^{-1}$ to $1.27(95 \%$ confidence interval $1.09,1.48)$ for mean nitrate levels above $14.85 \mathrm{mg} \cdot \mathrm{l}^{-1}$. An association between higher nitrate levels in domestic drinking water and incidence of childhood diabetes has been demonstrated. This was not explained by the ethnic composition of the population, population density or socioeconomic status. Nitrate in drinking water may be a precursor of chemicals which are toxic to the pancreas. [Diabetologia (1997) 40: 550-556]

Keywords Insulin-dependent diabetes mellitus, nitrate, water, childhood epidemiology, aetiology.
Insulin-dependent diabetes mellitus (IDDM) is a condition resulting from an autoimmune process in which insulin-producing pancreatic beta cells are destroyed. Its genetic susceptibility is closely linked with genes within the HLA region on the short arm of chromosome 6 [1]. Concordance rates range between 13 and

Received: 24 October 1996 and in revised form: 20 December 1996

Corresponding author: Dr. P. A. McKinney, Paediatric Epidemiology Group, Centre for Health Services Research, University of Leeds, 32 Hyde Terrace, Leeds, LS2 9LN, UK

A bbreviations: IDDM, Insulin-dependent diabetes mellitus; WSZ, water supply zone; ED, enumeration district; STZ, streptozotocin; SIR, standardised incidence ratio; PAF, postcode address file.
$50 \%$ for IDDM in monozygotic twins [2,3] suggesting environmental factors in its aetiology.

Many environmental exposures have been studied in relation to IDDM, the majority concentrating on diet or viral infections [4]. However, chemical toxins such as alloxan, chlorotocin and certain pesticides can poison pancreatic beta cells directly or trigger an immune response which damages these cells [5]. Particular attention has been focussed on nitrosamines and beta cell destruction as streptozotocin (STZ), a wide spectrum antibiotic, is also a nitrosamine specifically used as a toxin to induce IDDM in rats. STZ causes DNA strand breaks, selectively destroying beta cells either following single high doses or multiple low doses [6]. In humans, the reduction of ingested nitrate to nitrite and amination in the stomach to nitrosamines is well documented [7] and a limited 
number of previous studies have investigated the possible links between dietary intake of nitrate and nitrite and the incidence of IDDM. Helgason et al. [8] have shown that mice fed with a nitrosamine-rich diet of smoked and cured meat developed diabetes and sustained morphological damage to islet beta cells. In Scandinavia conflicting evidence has emerged from dietary studies of nitrate and nitrite $[9,10]$ and a case-control study in Australia found no association between estimated intake of nitrosamines from food and IDDM [11]. However, an ecological study in the United States [12] has demonstrated a significant positive correlation between levels of nitrate in drinking water and IDDM.

Estimates of daily nitrate intake in the United Kingdom vary between 64 and $297 \mathrm{mg} \cdot$ person $^{-1}$. day $^{-1}$ [13]. European Community Drinking Water Directive 80/778/EEC [14] defines a maximum acceptable concentration of nitrate in drinking water as $50 \mathrm{mg} \cdot \mathrm{l}^{-1}$ and recommends that levels do not exceed $25 \mathrm{mg} \cdot \mathrm{l}^{-1}$. In the United Kingdom, a nitrate level of $50 \mathrm{mg} \cdot \mathrm{l}^{-1}$ in drinking water is estimated to provide over $50 \%$ of total dietary nitrate intake [13]. The present study is the first in the United Kingdom to analyse the small area variation in levels of nitrate in drinking water in relation to the incidence of IDDM.

\section{Materials and methods}

Study population. The Yorkshire Register of Childhood Diabetes (YRCD) contains demographic details of 1797 children and young adults aged $0-16$ years who were diagnosed with IDDM while resident within the geographical area of the former Yorkshire Regional Health Authority. The register covers the period 1978-1994 and is estimated to be $97 \%$ complete [15]. Registrations are ascertained from three independent sources (hospital clinics, general practitioners and hospital episode statistics) and diagnosis of IDDM confirmed by hospital note abstraction. A postcode is identified for the residential address at diagnosis of each child on the register using the Postcode Address File (PAF) and located in the smallest areal unit of the 1991 decennial census, an Enumeration District (ED), using the Central Postcode Directory.

N itrate in drinking water. Water supplies in England are provided by 31 privately owned utilities which are regulated under the Water Industry Act 1991 [16]. Regulation 2 of the Water Supply (Water Quality) Regulations under that Act, requires supply companies to create distribution networks comprising 'water supply zones' (WSZ) supplying a maximum of 50000 people. The chemical composition of water supplied to every household within each WSZ is considered to be the same at any one time. Nitrate levels in drinking water for the study area were obtained from Yorkshire Water plc and the York Water Company. Complete data were only available from 1990 onwards for the entire study area and Figure 1 depicts its location and the WSZ boundaries. Sampling of treated water in the distribution network is carried out at both regular (usually monthly) and random intervals to ascertain biological and chemical composition. A sample taken in a WSZ will represent the water quality throughout the zone at that time. A total of
9330 water samples were analysed for nitrate content in 148 WSZs in Yorkshire over the period 1990-1995. Over the sampling period more than $81 \%$ of WSZs showed no significant linear change over time using linear regression. Of the remaining $19 \%, 16 \mathrm{WSZ}$ showed a decrease and 12 an increase in nitrate levels over time. A mean of the monthly mean nitrate level was taken to estimate an average level of nitrate load to account for short-term seasonal variation.

L inkage of WSZ to cases of IDDM. The geographical boundaries defining the WSZs and EDs (The 1991 Census, Crown Copyright. Education and Science Research Council purchase) were obtained in digital form. The 1991 census was the first census in which ED boundaries were digitised allowing geographical analyses at such a fine scale. EDs were assigned to the 148 WSZs using a Geographical Information System (GIS-ARC/INFO v 7.0). The two sets of boundary data were not entirely co-terminous and where an ED lay in more than one WSZ it was assigned to the WSZ which contained the largest proportion of its area. Systematic visual checking of the overlay confirmed that this method compensated for minor digitising errors in the original boundary data. In total, 1797 observed cases were assigned to 148 WSZs.

Population census data. Data from the 1991 Census (The 1991 Census, Crown Copyright. ESRC purchase Census Dissemination Unit, Manchester Computing Centre, University of Manchester, UK) were aggregated to provide a population structure for each WSZ. Population totals by age and sex, ethnicity (white or non-white), levels of car ownership, unemployment, owner-occupation and overcrowding were available for each WSZ. The 1991 Census is the first decennial census to provide information on ethnicity [17]. The latter four parameters were used to calculate the Townsend score, a measure of socioeconomic status with high indices indicating lower socioeconomic status [18]. Area-based population densities were calculated for children (0-16 years old) by dividing the respective populations in each ED by the area in hectares. The populationweighted average of the area-based population density for each of the EDs was aggregated to WSZs to provide population weighted population densities. This measure more accurately reflects the density at which the average person lives [19].

\section{Statistical analysis}

Statistical analyses were carried out using STATA [20]. Expected numbers of cases were derived using the age-sex stratum specific rates and census population totals. Standardised incidence ratios (SIRs) were calculated for IDDM in each WSZ as the ratio of observed to expected cases multiplied by 100. Univariate analyses examined the effect of mean nitrate levels, ethnicity, person-based population density and Townsend Score and its four components on SIR using the Poisson trend statistic [21].

The incidence of IDDM was assumed to be Poisson distributed and the data were fitted to a Poisson regression model together with significant risk factors from the univariate analysis - person-based childhood population density, childhood ethnicity and the Townsend Score. The number of cases in each WSZ was used as the dependent variable and the log of the expected number of cases used as the offset. The Townsend score and ethnicity were divided into two categories and population density and mean nitrate levels divided into three categories, all with approximately equal populations. A base model was created which included childhood person-based population 


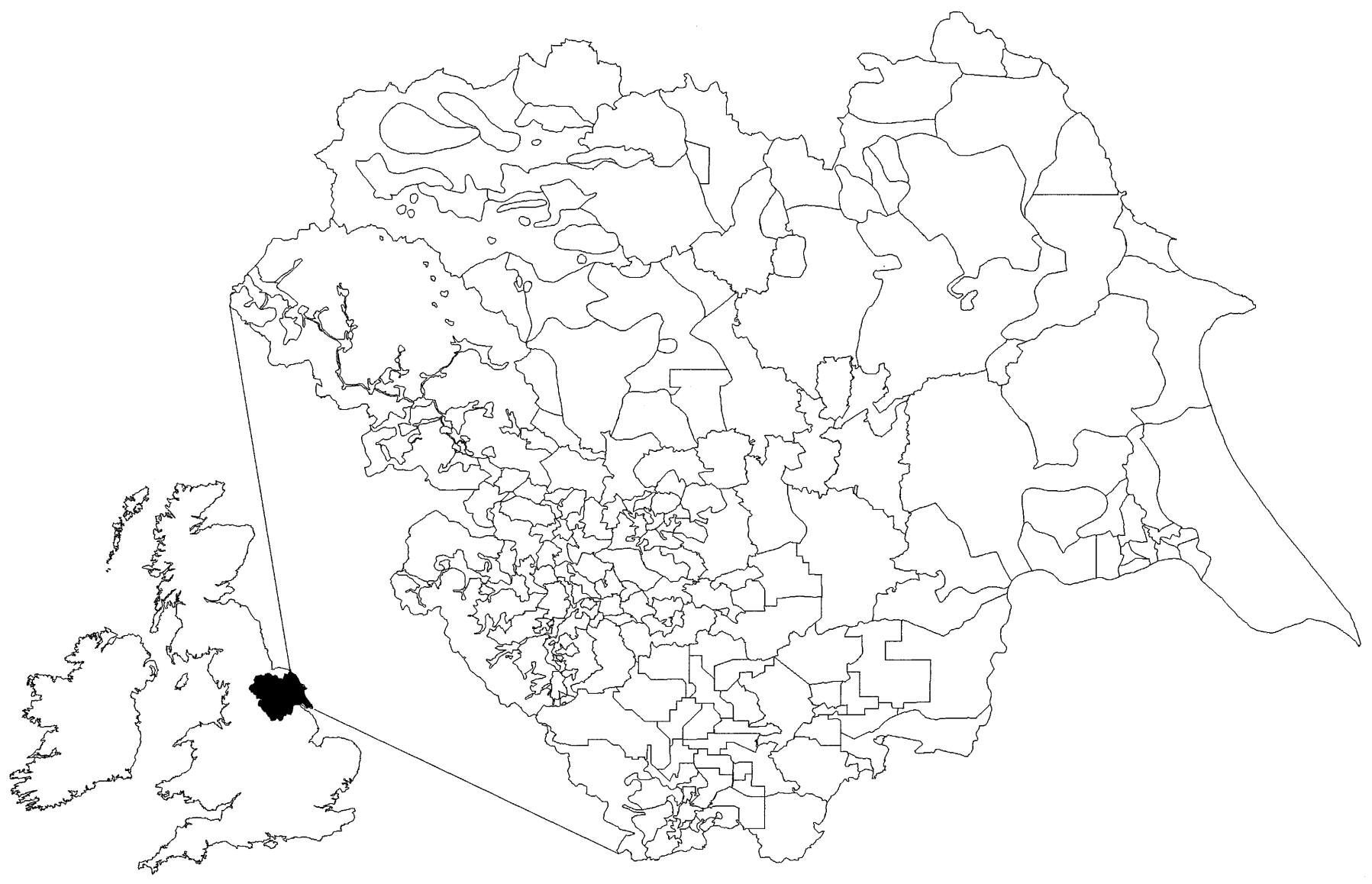

Fig. 1. Location of the study area and detail of the water supply zone boundaries

density, childhood ethnicity and Townsend score. The effect of adding mean nitrate levels to the model was calculated using the likelihood ratio test.

\section{Results}

Water Supply Z one nitrate levels and population characteristics. The distribution of the $148 \mathrm{WSZs}$ by nitrate levels averaged for each WSZ is shown in Figure 2 . The majority $(85 \%)$ of WSZs receive water with an average nitrate level below $25 \mathrm{mg} \cdot \mathrm{l}^{-1}$. This is based on 9330 individual water samples taken from 1990 to 1995 across the entire area, with an average of 63 samples per WSZ. From the total number of samples $2775(30 \%)$ exceeded $25 \mathrm{mg} \cdot \mathrm{l}^{-1}$ nitrate of which 31 $(0.11 \%)$ exceeded $50 \mathrm{mg} \cdot \mathrm{l}^{-1}$. Sixty-seven WSZs had at least one nitrate sample value greater than $25 \mathrm{mg} \cdot \mathrm{l}^{-1}$ and $12 \mathrm{WSZs}$ had at least one sample value exceeding $50 \mathrm{mg} \cdot \mathrm{l}^{-1}$. Table 1 details the underlying characteristics of the WSZs indicating the extent of variation in the data set in terms of population, geographical area and incidence of childhood IDDM.

Univariate analysis. Results of the univariate analysis are given in Table 2 for the effect of mean nitrate level, Townsend score, ethnicity and person-based population density on SIR. Mean nitrate levels showed a significant increase in SIR from 85 to 115 $\left(\chi^{2}\right.$ test for trend $\left.=26.81,1 \mathrm{df}, p<0.001\right)$, with a significant decrease in risk at the lowest level and significantly raised risk at the highest level. A significant decrease in SIR from 114 to 86 was observed with an increase in the proportion of non-whites in the population $\left(\chi^{2}\right.$ test for trend $\left.=33.57,1 \mathrm{df}, p<0.001\right)$. Areas of high person-based childhood population density were negatively associated with SIR which fell from 116 to 83 ( $\chi^{2}$ test for trend $\left.=34.43,1 \mathrm{df}, \mathrm{p}<0.001\right)$ as were the most deprived WSZs $\chi^{2}$ test for trend $=33.89,1 \mathrm{df}, \mathrm{p}<0.001)$.

Poisson regression modelling. There was an increase in relative incidence rate ratio to 1.27 from a baseline level of 1 for mean nitrate levels in the highest third ( $>14.85 \mathrm{mg} \cdot \mathrm{l}^{-1}$ nitrate) and the likelihood-ratio test shows a highly significant effect of adding mean nitrate to the fitted model $\left(\chi^{2}=9.53,2 \mathrm{df}, \mathrm{p}=0.009\right)$. The goodness of fit chi-square for the 'with nitrate model' suggests the data is Poisson distributed. Using the over-dispersion parameter $\alpha$, derived from a negative binomial regression model of the data, confirmed there was no evidence of over-dispersion $\left(\alpha=0.005, \chi^{2}=0.395,1 \mathrm{df}, p=0.53\right)$ [20]. An inspection of the residual deviance after model prediction displays no obvious spatial pattern. The standardised 


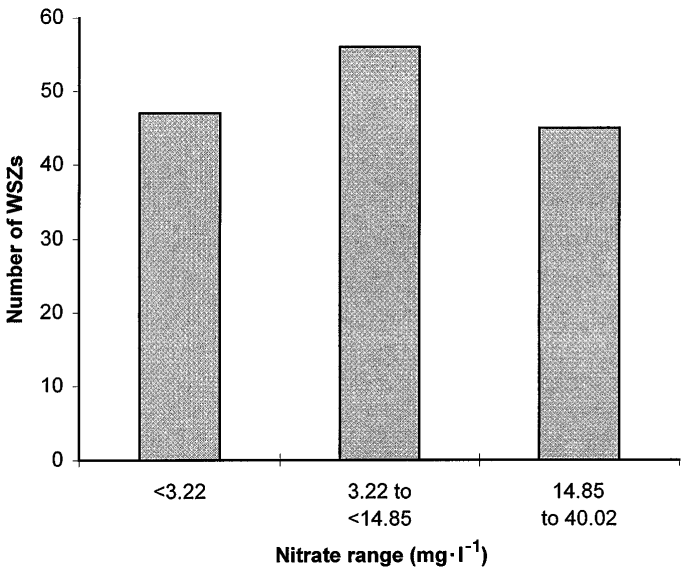

Fig. 2. Average nitrate levels in water supply zones 1990-1995

Table 1. Characteristics of water supply zones in Yorkshire

\begin{tabular}{lrlcr}
\hline $\begin{array}{l}\text { Water Supply Zone } \\
(\mathrm{n}=148)\end{array}$ & Mean & Minimum & Maximum & Total \\
\hline $\begin{array}{l}\text { Area hectares } \\
\begin{array}{l}\text { Population } \\
\text { (aged 0-16 years) }\end{array}\end{array}$ & 6780 & 91 & 61252 & 1003400 \\
$\begin{array}{l}\text { Area-based population } \\
\text { density (0-16 years }\end{array}$ & 12 & 12641 & 696032 \\
$\begin{array}{l}\text { per hectare) } \\
\begin{array}{l}\text { Person-based popula- } \\
\text { tion density }\end{array}\end{array}$ & 2.72 & 0.01 & 13.5 & - \\
$\begin{array}{l}\text { Observed number } \\
\text { of cases }\end{array}$ & 9.16 & 0.01 & 38.49 & - \\
$\begin{array}{l}\text { Incidence rate } \\
100,000^{-1} \cdot \text { year }^{-1}\end{array}$ & 12.14 & 0 & 43 & 1797 \\
\hline
\end{tabular}

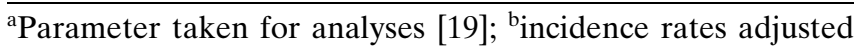
for age and sex

residuals were normally distributed and no single observation significantly altered the fit of the model.

A restricted analysis was performed using the 120 WSZs for which constant mean nitrate levels were recorded. The results were entirely consistent with the initial regression model, demonstrating that potential misclassification of nitrate exposure does not appear to affect the magnitude of the results.

\section{Discussion}

Our analysis of nitrate levels in Yorkshire drinking water and childhood diabetes shows a positive association between increased incidence of the disease and the nitrate content of domestic water.

Nitrate levels in drinking water vary according to the supply source which is in turn affected by climate and local geology. In addition, seasonal fluctuation in nitrate levels is observed. However, this variation affects the whole population of a WSZ equally although different WSZs may have different levels and frequencies of fluctuation. Individuals ingest nitrate via drinking water and food and nitrate is hypothesised as being potentially toxic due to the formation of nitrosamines in the body. An estimated $5 \%$ of dietary nitrate is reduced to nitrite, the chemical precursor of nitrosamines [22]. However, high intake of nitrate from drinking water may be more harmful than high intake from food as water does not contain nitrosation inhibitors such as vitamin $\mathrm{C}$ [10]. A Spanish ecological study of nitrate and cancer mortality suggested high consumption of local citrus fruits was protective for cancer mortality, even in areas with high levels of nitrate in drinking water [23]. No study has been conducted in the United Kingdom of variation in the consumption of bottled water at the level of water supply zones. However, a recent report has demonstrated that tap water consumption as a proportion of total liquid consumption has remained constant since 1978. For 0-5-year-olds, $67 \%$ of total liquid consumption is tap water [24].

Nitrosamines such as STZ, or nitrosamine-rich foods are recognised as specifically toxic to pancreatic beta cells in animal models $[6,25]$, conferring a degree of biological plausibility to the hypothesised deleterious effects in humans. Studies investigating this issue in human populations are extremely limited. Two case-control studies on children with IDDM in Scandinavia present conflicting results for intakes of nitrate and nitrite in food and drinking water $[8,9]$. In Finland, where the levels of nitrate in domestic water are particularly low $\left(<5 \mathrm{mg} \cdot \mathrm{l}^{-1}\right)$, there was no association between drinking water nitrate or nitrite levels and IDDM, although a relationship was found for dietary nitrite but not nitrate [10]. In Sweden, Dahlquist and colleagues in a case-control study of dietary factors demonstrated a dose response for intake of foods with a high nitrosamine content in relation to increased risk of developing diabetes [9]. Data from this study on intake of nitrate and nitrite was less clear-cut and more difficult to interpret.

An ecological study from Colorado, USA found a positive link between raised incidence of IDDM and levels of nitrate in drinking water [12], lending support to the findings of the present study. The two studies are not directly comparable since despite similar methodology and equivalent numbers of cases, the areal units of analysis were of a different order of magnitude. In Colorado the public supply system was infrequently tested and the level of public water supply within counties varied between 16 and $100 \%$. The 3.4 million population of Colorado was subdivided into 63 counties compared to the $148 \mathrm{WSZ}$ in Yorkshire with a population of 2.8 million. The sampling rate in the counties of Colorado was annual whereas the frequency for the WSZ was minimally 12 samples per year. The Yorkshire study provides a more comprehensive base for investigation than any previous research. 
Table 2. SIRs for IDDM by nitrate levels, ethnicity, population density and Townsend Score

\begin{tabular}{|c|c|c|c|c|c|c|c|c|}
\hline \multirow[b]{2}{*}{$\begin{array}{l}\text { Nitrate level }\left(\mathrm{mg} \cdot \mathrm{l}^{-1}\right) \\
\chi^{2}=26.81,1 \mathrm{df}, \mathrm{p}<0.001^{\mathrm{a}}\end{array}$} & $\begin{array}{c}\text { Range } \\
1.48\end{array}$ & \multirow[b]{2}{*}{$\begin{array}{r}<3.22 \\
<14.85 \\
40.01\end{array}$} & \multirow{2}{*}{$\begin{array}{l}\text { O } \\
498 \\
591 \\
708\end{array}$} & \multirow{2}{*}{$\begin{array}{l}\mathrm{E} \\
584 \\
598 \\
615\end{array}$} & \multirow{2}{*}{$\begin{array}{r}\text { SIR } \\
85 \\
99 \\
115\end{array}$} & \multicolumn{2}{|c|}{$95 \% \mathrm{CI}$} & $\begin{array}{l}\text { Population } \\
\text { (aged } 0-16 \text { years) }\end{array}$ \\
\hline & $\begin{array}{r}1.48 \\
3.22 \\
14.85\end{array}$ & & & & & $\begin{array}{r}78 \\
91 \\
107\end{array}$ & $\begin{array}{r}93 \\
107 \\
124\end{array}$ & $\begin{array}{l}225708 \\
232373 \\
237951\end{array}$ \\
\hline $\begin{array}{l}\text { Ethnicity } \\
\text { (proportion non-white) } \\
\chi^{2}=33.57,1 \mathrm{df}, \mathrm{p}<0.001^{\mathrm{a}}\end{array}$ & $\begin{array}{l}0.00 \\
0.02\end{array}$ & $\begin{array}{r}<0.02 \\
0.81\end{array}$ & $\begin{array}{r}1026 \\
771\end{array}$ & $\begin{array}{l}903 \\
894\end{array}$ & $\begin{array}{r}114 \\
86\end{array}$ & $\begin{array}{r}107 \\
80\end{array}$ & $\begin{array}{r}121 \\
93\end{array}$ & $\begin{array}{l}347966 \\
348066\end{array}$ \\
\hline $\begin{array}{l}\text { Townsend Score } \\
\chi^{2}=33.89,1 \mathrm{df}, \mathrm{p}<0.001^{\mathrm{a}}\end{array}$ & $\begin{array}{r}-5.09 \\
0.33\end{array}$ & $\begin{array}{l}<0.33 \\
13.66\end{array}$ & $\begin{array}{r}1021 \\
776\end{array}$ & $\begin{array}{l}898 \\
899\end{array}$ & $\begin{array}{r}114 \\
86\end{array}$ & $\begin{array}{r}107 \\
80\end{array}$ & $\begin{array}{r}121 \\
93\end{array}$ & $\begin{array}{l}343607 \\
352425\end{array}$ \\
\hline
\end{tabular}

${ }^{\mathrm{a} A l l} \chi^{2}$ for trend

O, Observed number of cases; E, expected number of cases; SIR, standardised incidence ratio; CI, confidence interval

Table 3. Comparison of incidence rate ratios ( $95 \% \mathrm{CI}$ ) for different mean nitrate levels in drinking water, Townsend Score, ethnicity, and person-based population density in a Poisson regression model

\begin{tabular}{|c|c|c|c|c|}
\hline & \multicolumn{4}{|c|}{ Model incidence rate ratios $(95 \% \mathrm{CI})$} \\
\hline & Range & & $\begin{array}{l}\text { Without } \\
\text { nitrate }\end{array}$ & $\begin{array}{l}\text { With } \\
\text { nitrate }\end{array}$ \\
\hline $\begin{array}{l}\text { Population density } \\
\text { (aged } 0-16 \text { years, per hectare) }\end{array}$ & $\begin{array}{c}0.1 \\
8.27 \\
13.25\end{array}$ & $\begin{aligned}< & 8.27 \\
< & 13.25 \\
& 38.49\end{aligned}$ & $\begin{array}{l}1 \\
0.97(0.86,1.09) \\
0.88(0.75,1.04)\end{array}$ & $\begin{array}{l}1 \\
0.93(0.82,1.05) \\
0.85(0.71,1.01)\end{array}$ \\
\hline $\begin{array}{l}\text { Mean nitrate level } \\
\left(\mathrm{mg} \cdot \mathrm{l}^{-1}\right)\end{array}$ & $\begin{array}{r}1.48 \\
3.22 \\
14.85\end{array}$ & $\begin{aligned}< & 3.22 \\
< & 14.85 \\
& 40.01\end{aligned}$ & $\begin{array}{l}- \\
- \\
-\end{array}$ & $\begin{array}{l}1 \\
1.11(0.98,1.26) \\
1.27(1.09,1.48)\end{array}$ \\
\hline $\begin{array}{l}\text { Model goodness of fit } \chi^{2} \\
\text { Likelihood ratio test }\end{array}$ & \multicolumn{4}{|c|}{$\chi^{2},=9.53,2 \mathrm{df}, p=0.009$} \\
\hline
\end{tabular}

The rates of IDDM in Yorkshire were 15\% above that expected for the entire area in the WSZ where mean nitrate levels exceeded $14.85 \mathrm{mg} \cdot \mathrm{l}^{-1}$. These levels were well within the acceptable maximum $50 \mathrm{mg} \cdot \mathrm{1}^{-1}$ recommended by the European Community [14], although it is also recommended that levels do not exceed $25 \mathrm{mg} \cdot \mathrm{l}^{-1}$. The study results are based on an analysis of a large geographical area and a substantial number of cases but the heterogeneous distribution of the high level WSZ across the study area make individual identification of specific high-risk areas inappropriate. The observations of our Yorkshire study find some support in the limited literature available but should be considered as hypothesis-generating.

An ideal assessment of nitrate exposure would record measurements of an individual's intake. However, the underlying assumption that exposure of a population represents that of the individual is considered to apply in these circumstances for the following reasons. Firstly, domestic water is distributed to relatively small populations of approximately equal size (50000 persons) and the chemical composition of the water supplied within each WSZ is homogeneous. Thus, individual households within a WSZ will receive water of equivalent quality.

Secondly, the assumption that nitrate levels from measurements made between 1990 and 1995 represent likely exposure over the longer period of case collection (1978-1994) is based on the following evidence. Significant temporal trends in nitrate levels are absent in $81 \%$ of WSZs for the recent time period, 1990-1995. However, over the preceding two decades, the water supply companies report decreasing levels suggesting that recent measurements are conservative. For the remaining WSZs displaying either increasing $(n=12)$ or decreasing $(n=16)$ levels, misclassification of exposure does not influence our findings, as their removal from the Poisson regression model had no effect on the overall results. The climate and geology of the study area has not altered over the last 30 years and changing patterns of land 
use are more likely to have resulted in reductions of nitrate levels in recent years. Our measures of exposure are therefore considered to be conservative. An investigation of drinking water nitrate and cancer in urbanised areas of the United Kingdom, found minimal variation in nitrate levels over time [26]. Close examination of the Yorkshire data, sample by sample for each WSZ, clearly showed that the mean level of nitrate adequately expressed the exposure level for the area and was an appropriate parameter for analysis. A German study of primary brain tumours, comparing an area-based survey of water nitrate levels and semi-quantitative measurement of nitrate in subjects' drinking water, showed correlations [27] which add further support to the use of mean levels for an area reflecting the exposure to individuals.

The high quality of the register used, in conjunction with the systematically collected water nitrate data has presented a unique opportunity to investigate the relationship between the occurrence of IDDM in children and levels of nitrate across a large area comprising varied geology and land use. Children are located by their residence at the time of diagnosis and their previous length of stay in the area is unknown. However, it is established from a study of childhood leukaemia that migration of children in Yorkshire is generally restricted to small localities and few children will have left the area to be diagnosed elsewhere [28]. The inclusion of subjects who spent their lives outside the study area but moved in prior to diagnosis will counterbalance this effect. No large-scale systematic migration pattern is apparent to suggest that the majority of cases were not exposed to the measured nitrate levels.

The present study has compensated for known confounding factors as certain area-based features of populations are known to be linked to IDDM incidence; however co-varying factors, such as underlying geology, for nitrate levels are impossible to assess in the context of the current study. The following three specific risk factors for IDDM were selected a priori to investigate as potential explanatory variables for variation in incidence - population density, ethnicity and deprivation. The proportion of non-white children was included as a variable as McKinney et al. [29] have found reduced incidence of childhood onset IDDM in some local government districts in Yorkshire with high proportions of non-white children. Similarly, the effect of population density has been associated with incidence of IDDM [21]. A higher risk of IDDM in rural compared to urban areas has been shown in Yorkshire [29] and elsewhere [30]; however, the small geographical areas and similar population base comprising the WSZs prevented any meaningful analysis of the effect of urban/rural status. Low rates of IDDM are present in the Asian subcontinent and certain districts in the county of West Yorkshire have up to $28.2 \%$ non-white children in the population. Recent geographical analyses have shown low rates in these areas [29] and the significance of this has been confirmed by the clear association using the WSZ as the unit of analysis. Residence in affluent areas has been demonstrated as increasing risk on a small geographical scale $[30,31]$ and again this was shown to be the case in our study. Both ethnicity and deprivation are correlated in small census areas with population density and a person-based measure of population density [19] was selected for analysis. All variables, significant at the univariate level, were potentially explanatory in the Poisson regression analysis. However, the results of the multivariate approach clearly showed that mean nitrate levels had an independent effect on the variation in incidence which was not explained by the associations with ethnicity, deprivation or population density.

In conclusion, this ecological analysis makes a strong case for further investigation of the diabetogenic effect of nitrate in the diet and the contribution of nitrate levels in drinking water. Questions that still need to be answered are the relative effect of consumption of nitrate in food and drinking water, age when exposure is most important, whether shortterm exposure to high nitrate levels are more important than mean exposure over time. More detailed analyses of nitrate in diet including drinking water are required in order to make more robust conclusions.

A cknowledgements. We are grateful to Yorkshire Water plc for providing digitised boundary data and nitrate sample data, to York Water Company for providing nitrate sample data and to Dr. J. Barrett for statistical advice. All paediatricians, clinicians and diabetes specialist nurses are thanked for assisting Ms. C. Stephenson, Ms. H. Lilley and Dr. K. Gurney with assiduous data collection. Funding: Children's Research Fund, Northern and Yorkshire NHS Research and Development, The General Infirmary at Leeds Special Trustees, Dr. G. Law was supported by a Leeds University Postgraduate Scholarship, Novo Nordisk.

\section{References}

1. Todd JA (1995) Genetic analysis of type 1 diabetes using whole genome approaches. Proc Nat Acad Sci USA 92: 8560-8565

2. Kaprio J, Tuomilehto J, Koskenvuo M et al. (1992) Concordance for type 1 (insulin-dependent) and type 2 (non-insulin-dependent) diabetes mellitus in a population-based cohort of twins in Finland. Diabetologia 35: 1060-1067

3. Kyvik KO, Green A, Henning B-N (1995) Concordance rates of insulin dependent diabetes mellitus: a population based study of young Danish twins. BMJ 311: 913-917

4. Bach J-F (1994) Insulin-dependent diabetes mellitus as an autoimmune disease. Endocrine Reviews 15: 516-542

5. Assan R, Larger E (1993) The role of toxins.In: Leslie RDG (ed) Causes of diabetes: genetic and environmental factors. John Wiley, Chichester, pp 105-123 
6. Dulin WE, Soret MG (1978) Chemically and hormonally induced diabetes. In Volk BW, Welman KE (eds) The diabetic pancreas. Plenum Press, New York, pp 425-437

7. International Agency for Research on Cancer (1987) The relevance of N-nitroso compounds to human cancer: exposures and mechanisms. IARC Scientific Publications No. 84. IARC, Lyon

8. Helgason T, Ewen SWB, Ross IS, Stowers JM (1982) Diabetes produced in mice by smoked/cured mutton. Lancet 2: 1017-1021

9. Dahlquist G, Blom LG, Persson LA, Sandström AIM, Wall SGI (1990) Dietary factors and the risk of developing insulin dependent diabetes in childhood. BMJ 300: 1303-1306

10. Virtanen SM, Jaakkola L, Räsänen L et al. (1994) Nitrate and nitrite intake and the risk for type 1 diabetes in Finnish children. Diabet Med 11: 656-662

11. Verge CF, Howard NJ, Irwig L, Simpson JM, Mackerras D, Silink M (1994) Environmental factors in childhood IDDM: a population-based, case-control study. Diabetes Care 17: 1381-1389

12. Kostraba JN, Gay EC, Rewers M, Hamman RF(1992) Nitrate levels in community drinking waters and risk of IDDM. An ecological analysis. Diabetes Care 15: 15051508

13. Chilvers C, Inskip H, Caygill C, Bartholemew B, Fraser P, Hill MA (1984) A survey of dietary nitrate in well-water users. Int J Epidemiol 13: 324-331

14. EEC (1980) Council directive on the quality of water for human consumption. Official Journal of the EEC 229: $11-$ 29

15. Staines A, Bodansky HJ, Lilley HEB, Stephenson C, McNally RJQ, Cartwright RA (1993) The epidemiology of diabetes mellitus in the United Kingdom: the Yorkshire Regional Childhood Diabetes Register. Diabetologia 36: 1282-1287

16. HMSO (1991) Water Industry Act 1991. HMSO, London

17. Office of Population Censuses and Surveys (1996) Ethnicity in the 1991 census. (Eds) Coleman D, Salt J. HMSO, London

18. Phillimore P, Beattie A, Townsend P (1994) Widening inequality of health in northern England, 1981-91. BMJ 308: 1125-1128

19. Dorling D, Atkins D (1995) Population density, change and concentration in Great Britain 1971, 1981 and 1991. Studies on medical and population subjects No. 58. HMSO, London

20. StataCorp (1995) Stata Statistical Software: Release 4.0. Stata Corporation College Station, TX

21. Breslow NE, Day NE (1987) Statistical methods in cancer research. Vol 2. The design and analysis of cohort studies. (IARC Scientific Publications No. 82), IARC, Lyon

22. Choi BCK (1985) N-nitroso compounds and human cancer: a molecular epidemiologic approach. Am J Epidemiol 121(5):737-743

23. Morales-Suarez-Varela MM, Llopis-Gonzalez A, Terjerizo-Perez ML (1995) Impact of nitrates in drinking water on cancer mortality in Valencia, Spain. Eur J Epidemiol 11: $15-21$

24. M.E.L Research (1996) Tap water consumption in England and Wales: findings from the 1995 national survey. M.E.L Research Report 9448/01. Crown Copyright 1996, UK

25. LeDoux SP, Hall CR, Forbes PM, Patton NJ, Wilson GL (1988) Mechanisms of nicotinamide and thymidine protection from alloxan and streptozotocin toxicity. Diabetes 37: 1015-1019

26. Beresford SAA (1985) Is nitrate in the drinking water associated with the risk of cancer in the urban UK? Int J Epidemiol 14: 57-63

27. Steindorf K, Schlehofer B, Becher H, Hornig G, Wahrendorf J (1994) Nitrate in drinking water. A case-control study on primary brain tumours with an embedded drinking water survey in Germany. Int J Epidemiol 23: 451-457

28. Alexander FE, McKinney PA, Cartwright RA (1993) Migration patterns of children with leukaemia and non-Hodgkin's lymphoma in three areas of Northern England. J Public Health Med 15(1):9-15

29. McKinney PA, Law G, Bodansky HJ, Staines A, Williams DRR (1996) Geographical mapping of childhood diabetes in the northern county of Yorkshire. Diabet Med 13(8):734-740

30. Patterson CC, Waugh NR (1992) Urban/rural and deprivational differences in incidence and clustering of childhood diabetes in Scotland. Int J Epidemiol 21: 108-117

31. Patterson CC, Carson DJ, Hadden DR (1996) Epidemiology of childhood IDDM in Northern Ireland 1989-1994: Low incidence in areas with highest population density and most household crowding. Diabetologia 39: 1063-1069 